\author{
ОРГАНИЗАЦИЯ ДОСУГА ДЕТЕЙ И ПОДРОСТКОВ \\ В КАДЕТСКИХ КОРПУСАХ РОССИЙСКОЙ ИМПЕРИИ \\ В КОНЦЕ ХІХ — НАЧАЛЕ ХХ В. \\ (ПО МАТЕРИАЛАМ ЖУРНАЛА «ВОЕННАЯ БЫЛЬ»)
}

\begin{abstract}
А. В. АГЕЕВА
В статье рассматриваются формы организации досуга детей и подростков, практиковавшиеся в кадетских корпусах Российской империи в конце XIX - начале XX в. Основным источником исследования послужили воспоминания бывших воспитанников кадетских корпусов, опубликованные в журнале «Военная быль» в период с 1952 по 1974 г. Наряду с традиционными видами досуга, такими как спортивные игры, экскурсии и походы, в источниках описываются более сложные формы его организации - корпусные музеи, рукописные кадетские журналы, кадетский летний лагерь в Петергофе, литературномузыкальные вечера и спектакли. Анализ источников позволяет сделать вывод о многообразии видов досуга кадет, выявить общие формы досуга, характерные для всех учебных заведений такого рода и уникальные, встречающиеся в отдельно взятых кадетских корпуcax, а также выяснить некоторые методические особенности их организации.
\end{abstract}

«Военная быль» - журнал, созданный участниками «Общекадетского объединения», в силу исторических обстоятельств оказавшихся вдали от Родины, разбросанных по разным странам, но желавших сохранить память о малоизвестных эпизодах Первой мировой и Гражданской войн, о быте и традициях Русской Императорской армии и флота, а также уникальной атмосфере кадетских корпусов и других военно-учебных заведений, в которой были воспитаны. Журнал выпускался с 1952 по 1974 г. За это время в нем опубликовали свои воспоминания многие русские офицеры, жившие в эмиграции, но когда-то носившие кадетские погоны российских корпусов.

Кадетские корпуса, по выражению С. Двигубского, были самыми «характерными» учебными заведениями России. Характер этот выражался в традиционном воспитании и исключительной любви воспитанников к своему учебному заведению ${ }^{1}$. В среде выпускников не существовало понятия «бывший кадет», такое словосочетание было применимо лишь к тем, кто по каким-то причинам был отчислен из корпуса. Остальные твердо знали: кадет - это навсегда, на всю жизнь.

Учебная и воспитательная часть кадетских корпусов достаточно описана в педагогических исследованиях, поэтому обратимся к вопросам организации до-

\footnotetext{
${ }^{1}$ Двигубский С. Кадетские корпуса // Военная быль. 1952. № 1. С. 5-6.
} 
А. В. Агеева. Организация досуга детей и подростков в кадетских корпусах Российской империи...

суга воспитанников, опираясь на их собственные воспоминания. С этой целью рассмотрим мемуары кадет Пажеского Его Императорского Величества корпуса, Первого кадетского корпуса, Императора Александра II корпуса, Владикавказского кадетского корпуса, Владимирского Киевского кадетского корпуса, Донского императора Александра III кадетского корпуса, Одесского великого князя Константина Константиновича кадетского корпуса, Оренбургского Неплюевского кадетского корпуса, 2-го Оренбургского кадетского корпуса, Орловского Бахтина кадетского корпуса, Петровского Полтавского кадетского корпуса, Псковского кадетского корпуса, Сумского кадетского корпуса, Ташкентского наследника цесаревича великого князя Алексея Николаевича кадетского корпуса, Ярославского кадетского корпуса. Нами не рассматривались особенности организации досуга в Морском наследника цесаревича великого князя Алексея Николаевича кадетском корпусе ввиду его специфики, а также в Первом Русском великого князя Константина Константиновича кадетском корпусе, как возникшем в среде русской эмиграции в особых исторических условиях.

Досуг играл в жизни кадет весьма важную роль. С одной стороны, это была необходимая для учащихся психологическая разгрузка, позволявшая ненадолго отвлечься от строгой корпусной дисциплины, пообщаться с товарищами в неформальной обстановке, уделить время любимым занятиям, выходящим за рамки учебного процесса. С другой стороны, организованный досуг являлся гармоничным дополнением основных положений воспитательной системы, он был призван содействовать укреплению корпусных традиций и воспитанию детей и подростков в этих традициях. Таким образом, мы можем говорить о формах досуга, сложившихся в результате организации отдыха кадет руководством корпуса и его самоорганизации. Иногда встречаются промежуточные формы досуга, при которых инициатива принадлежала одной стороне, а организацией занималась другая.

Анализ источников позволяет нам выделить следующие формы досуга:

- внеклассные занятия и свободное время, предусмотренные распорядком дня;

- корпусные музеи;

- кадетское чтение;

- литературно-музыкальные вечера и корпусные праздники;

• гимнастические смотры и спортивные праздники;

- кадетский лагерь в Петергофе;

• посещение выставок, походы и юбилейные экскурсии по России.

Рассмотрим подробнее каждый из перечисленных видов.

Внеклассные занятия и свободное время, предусмотренные распорядком дня

По свидетельству А. Брофельда, программа обучения в кадетских корпусах предусматривала наличие классных и внеклассных занятий. Последние делились на два разряда - обязательные (к ним относились гимнастика, фехтование, стрельба, строевая подготовка, плавание, танцы) и необязательные - пение, 
музыка и разнообразный ручной труд; в большинстве кадетских корпусов были организованы хор певчих, духовой и балалаечный оркестры ${ }^{2}$. На такие необязательные занятия в распорядке дня отводилось время с 16 до 18 часов. Для организации ручного труда также создавались все необходимые условия. Желающие получали навыки работы на токарных станках, столярного мастерства; обучались резьбе по дереву. В Киевском кадетском корпусе кадеты, увлекавшиеся ручным трудом, сами делали резные шкафы для библиотеки, киоты к образам, их усилиями была создана даже корпусная лодка³. Воспитанники, не имевшие способностей к музыке, пению и ручному труду или не желавшие ими заниматься, могли проводить свободное время по своему усмотрению.

Иногда досуг организовывался офицерами-воспитателями в соответствии с пожеланиями кадет. Например, при кадетском корпусе Императора Александра II для желающих были устроены занятия верховой ездой в Манеже; в конце сезона - конный праздник ${ }^{4}$. Директор этого корпуса А. И. Калишевский каждый год получал в охотничьих хозяйствах разрешение на участие нескольких кадет старших классов в осенней охоте 5 . При Владимирском Киевском кадетском корпусе по желанию кадет была создана команда самокатчиков ${ }^{6}$, отрабатывавших навыки езды на велосипеде и выступавших позднее на корпусных спортивных праздниках ${ }^{7}$.

Отметим, что увлечения кадет не всегда носили безопасный характер. В. Цимбалюк упоминает об увлечении группой старших кадет Ярославского корпуса самодельной пиротехникой ${ }^{8}$. Он же пишет, что во время его пребывания в Сумском кадетском корпусе старшие ребята проводили опыты с полетами на бипланах, ими же самими построенных. Кадеты успели провести несколько полетов, но начальство корпуса запретило дальнейшие испытания9. Об этой единственной в истории «кадетской авиации» рассказывает также Б. Ряснянский ${ }^{10}$.

Досуг младших кадет носил иной характер. Часто ребята использовали свободные минуты только для того, чтобы устроить обычную мальчишескую возню. А. А. Ветлиц и В. Каменский, учившиеся соответственно в Первом и Александровском кадетских корпусах, называют несколько таких игр:

- «Куча-мала». Суть игры заключалась в том, чтобы сбить с ног товарища и навалиться на него всей компанией. Кадеты, замечавшие лежаших, разбегались

\footnotetext{
${ }^{2}$ Брофельд А. Кадетские корпуса Российской Империи // Военная быль. 1964. № 67. C. $13-18$.

${ }^{3}$ Дубинский В., Аустрин Г. Владимирский Киевский кадетский корпус // Военная быль. 1967. № 83. С. $1-14$.

${ }^{4}$ Кочетов Ф. Манежная езда и конный праздник // Военная быль. 1960. № 40. С. 20-21.

${ }_{5}^{5} \Phi . K$. Кадетская охота (Из цикла «Корпус императора Александра II») // Военная быль. 1959. № 36. С. $18-19$.

${ }^{6}$ Самокатчики - военнослужащие велосипедных (самокатных) подразделений. Здесь: кадеты, занимавшиеся велосипедной ездой.

7 Дубинский, Аустрин. Владимирский Киевский кадетский корпус // Военная быль. 1967. № 83. С. 1-14.

${ }^{8}$ Цимбалюк В. Пиротехники // Военная быль. 1961. № 49. С. 43-45.

${ }^{9}$ Цимбалюк. Авиаторы // Военная быль. 1959. № 36. С. 16-17.

${ }^{10}$ Ряснянский Б. Сумский кадетский корпус: Воспоминания // Военная быль. 1971. № 112. C. $6-12$
} 
А. В. Агеева. Организация досуга детей и подростков в кадетских корпусах Российской империи...

и прыгали сверху. Задача того, кто оказывался внизу, состояла в том, чтобы выбраться «на воздух».

- Игра «в козла» выглядела следующим образом: кадеты делились на команды по нескольку человек, и одна команда прыгала на другую. Интерес игры заключался в том, чтобы все прыгавшие сели на 2-3 человек, стоявших согнувшись друг за другом, и повалили их на пол. Если стоявшие ребята падали под тяжестью товарищей, они считались проигравшими, если нет - выигрывали.

- «Жгуты». Участники игры вставали в круг, держа руки за спиной. Один из играющих ходил за их спинами, держа намоченное и свернутое в виде жгута полотенце, и незаметно вкладывал его в руки одного из играющих. Последний сразу начинал лупить полотенцем соседа справа. Тот уворачивался от своего «обидчика», обегал круг и вставал на свое место.

- Игра, название которой не указывается. Водящий вставал у стены, упершись в нее головой и держа в напряжении ноги. Остальные игроки кидали в него черным резиновым мячом, стараясь попасть в самое уязвимое место - под колени. Если кидающий промахивался, он занимал место водящего и игра продолжалась.

- «Верблюд». Трое или четверо крепких ребят становились друг за другом, положив руки на плечи впередистоящего. На эти руки усаживались еще двое или трое мальчиков, на них, в свою очередь, карабкался еще один. Цель игры заключалась в том, чтобы получившийся «верблюд» смог, не рассыпавшись, обойти залу.

- «Томашевский толкается.» Игра получила название по фамилии кадета, которого стали толкать остальные при ее первом применении. Впоследствии кто-то из кадет громко произносил эту фразу, но с любой другой фамилией, после чего ребята хватали того кадета, чья фамилия прозвучала, и кидали его от одной собравшейся группе к другой.

Кроме того, между кадетами была определенная «мода» съезжать вниз по перилам. Некоторые ребята достигали в этом «виде спорта» большого мастерства. Все это проделывалось, конечно, не на глазах у начальства ${ }^{11}$.

Существовали в кадетской среде и более спокойные игры. Так, В. Каменский говорит об игре «в облатки» («в перышки»), смысл которой заключался в том, чтобы накрыть своей облаткой (небольшой бумажкой, которой заклеивали конверты с письмами) облатку товарища, нажав на нее определенным образом ${ }^{12}$. В Псковском кадетском корпусе кадеты играли в подстенок. По свидетельству М. Данилевича, в Оренбургском Неплюевском кадетском корпусе «дядьки», выполнявшие некоторые обязанности прислуги, учили старших кадет плести рыболовные сети, а младшим вырезали из дерева кубари. Эти кубари кадеты на переменах гоняли по паркету с помощью маленьких кнутов ${ }^{13}$.

${ }^{11}$ Ветлии А. Первый кадетский корпус // Военная быль. 1962. № 54. С. 29-30; Каменский В. Воспоминания об Александровском кадетском корпусе // Военная быль. 1973. № 124. C. 25.

${ }^{12}$ Каменский. Указ. соч. С. 24.

${ }^{13}$ Данилевич М. Оренбургский Неплюевский кадетский корпус (1825-1960) // Военная быль. 1960. № 45. С. 10-11; 1961. № 46. С. 12-13. 
Своеобразной формой проведения досуга для кадет являлось попадание в корпусной лазарет, особенно беспричинное, благодаря некоторым хитрым манипуляциям с градусником. О таком «лазаретном» досуге пишут В. Каменский и М. Каратеев ${ }^{14}$. В. Каменский уточняет, что любимым развлечением в лазарете было обрызгивание друг друга (особенно новичков) водой из фонтанов, а также устройство между койками «шалашей» и «вигвамов» из простыней и одеял. Отметим, что авторы единодушны в своей положительной оценке времени, проведенного в стенах лазарета, хотя и являются выпускниками разных корпусов.

Помимо двух часов свободного времени распорядком дня были предусмотрены две большие перемены (утром и днем), во время которых кадетам не возбранялось играть в шумные, подвижные игры. Так, А. С. Гершельман в своих рассказах о Пажеском корпусе пишет, что зимой во время большой перемены кадеты играли в снежки, катались на салазках с горки и, по его выражению, устраивали «беготню по сугробам» ${ }^{15}$. А. В. Борщов, воспитанник Первого кадетского корпуса, рассказывает о зимних забавах более подробно: «Любимым зимним спортом кадет было катание на коньках по плацу и две ледяные горы, с которых скатывались на “лубках". Большим развлечением были также “баталии” на снежках. Обычно сражались класс против класса или отделение против отделения, но я помню одно грандиозное сражение: 1-я и 4-я роты против 2-й и 3-й. Офицеры-воспитатели принимали горячее участие в этом сражении. Как правило, пленных “купали” в рыхлом снегу»" время года ребята с удовольствием играли в лапту. А. А. Ветлиц добавляет, что кроме лапты успехом пользовались такие игры, как городки и футбол, В. Каменский упоминает игру в «казаки-разбойники», Г. Месняев - также игру в городки. Кроме того, известно, что иногда игры приобретали азартный характер - за неимением денег кадеты играли на еду. При Орловском корпусе Бахтина, который располагался на довольно большом участке земли, для кадет на улице были построены «гигантские шаги», кегельбан и теннисный корт ${ }^{17}$. В Сумском кадетском корпусе старшие ребята имели возможность играть в бильярд.

Во время Рождественских и Пасхальных каникул для кадет, остававшихся в стенах корпуса, устраивались разнообразные развлечения. Воспитанник Александровского кадетского корпуса В. Каменский пишет о поездках в театры и цирк, о елке с подарками ${ }^{18}$. В Первом кадетском корпусе существовала иная традиция: елку устраивали силами самих кадет для детей обслуживающего персонала.

${ }^{14}$ Каменский. Корпусный лазарет: Из цикла «Корпус императора Александра II» // Военная быль. 1960. № 41. С. 20-22; Каратеев М. Лазаретные воспоминания // Военная быль. 1961. № 46. С. $17-19$.

${ }^{15}$ Гершельман A. С. Один из сорока трех (отрывок) // Военная быль. 1972. № 114. С. 37. C. 14.

${ }^{16}$ Борщов А. В. Воспоминания о Первом кадетском корпусе // Военная быль. 1969. № 97.

${ }^{17}$ Месняев Г. Кадетские годы (1902-1909) // Военная быль. 1954. № 11. С. 2-6; 1955. № 12. C. 4-9; № 13. С. 6-10; № 14. С. 9-13; № 15. С. 4-7; 1956. № 16. С. 7-12.

${ }^{18}$ Каменский. Воспоминания об Александровском кадетском корпусе // Военная быль. 1973. № 124. С. 22-26. 
А. В. Агеева. Организация досуга детей и подростков в кадетских корпусах Российской империи...

Корпусные музеи

Музей при Первом кадетском корпусе был создан в конце XVIII в. директором корпуса графом Ф. Е. Ангальтом. В исследуемый нами период музей представлял собой собрание рукописных книг, созданных кадетами, наглядных пособий и редких произведений искусства, каким-либо образом связанных с историей корпуса. Кадеты имели возможность в свободное время посещать музей, находившийся в «Рекреационной зале». Однако первые годы существования музея напрямую связаны с организацией полезного досуга кадет, поэтому позволим себе отступить от хронологических границ исследования и уделить немного внимания более раннему периоду. А. Н. Антонов, много лет бывший хранителем музея, так пишет об этой эпохе: «При Ангальте музеем служила обширная зала, где кадеты... в часы досуга могли получать духовное удовлетворение, предаваясь чтению, письму, рисованию и даже личному творчеству... В этой зале кадеты... занимались чтением с выпискою тех мест, которые останавливали их внимание. Затем занимались черчением, рисованием, резьбой и т. п. Лучшие работы выставлялись в этой зале как образцы» ${ }^{19}$. Заметим, что, по свидетельству того же А. Н. Антонова, со времен Ангальта в музее осталось около трехсот томов рукописных кадетских книг, носивших сказочное название - «Тысяча и одна ночь». Это свидетельствует о популярности такого рода досуга. Не все кадетские записи отличались серьезностью содержания. Например, известно, что среди них были «Письма с того света» («с Елисейских полей»), в которых рассказывалось, как Вольтер и Жан Жак Руссо «оттуда» пишут письма кадетам корпуса.

Музеи существовали также при Суворовском, Полтавском, Ташкентском и некоторых других кадетских корпусах. К сожалению, об их роли в организации досуга кадет в источниках не упоминается.

\section{Кадетское чтение}

Чтение оказывает огромное влияние на формирование личности ребенка и подростка, поэтому в кадетских корпусах подбору литературы уделялось особое внимание. По воспоминаниям А. В. Борщова, между кадетами его роты и офицером-воспитателем существовало неписаное правило: все книги, приносившиеся кадетами в корпус, сдавались на подпись воспитателю. Воспитатель (Б. А. Петровский) не только оставлял на книгах свой автограф, но и давал советы и высказывал свои замечания по поводу книги. Книги без подписи воспитателя изымались ${ }^{20}$. Наряду с книгами, отобранными для библиотек военно-учебных заведений, широкое распространение получили кадетские журналы и сборники.

Первый журнал такого рода под названием «Праздное время, в пользу употребляемое» начал выходить в Шляхетском сухопутном кадетском корпусе в 1759 г. Отметим, что журнал выпускали сами кадеты, правда, с подсказки начальства корпуса. В 1853 г. начальник штаба военно-учебных заведений Я. И. Ростовцев с одобрения императора Николая I начинает выпуск «Журнала для чтения

\footnotetext{
${ }^{19}$ Антонов А. Музей Первого кадетского корпуса // Военная быль. 1965. № 77. С. 38.

${ }^{20}$ Борщов. Воспоминания о Первом кадетском корпусе // Военная быль. 1969. № 96. C. $10-16$.
} 
воспитанникам военно-учебных заведений». Журнал состоял из следующих разделов: изящная словесность, науки, история, искусство, разное («смесь»). Издание выпускалось на протяжении 30 лет, рассылалось по всем военно-учебным заведениям и пользовалось большой популярностью.

В 1903 г. преподавателями военно-учебных заведений поднимается вопрос о пользе и необходимости издания ученических журналов. С этого времени появляется множество кадетских ученических сборников, не только чтение, но и подготовка которых стала для многих воспитанников содержательным досугом. В таблице представлены данные о кадетских сборниках, размещенные А. Т-овым и А. Савченко в журнале «Военная быль» ${ }^{21}$. Сборники перечислены в алфавитном порядке.

Таблииа

Ученические сборники, выпускавшиеся в российских кадетских корпусах в начале XX века

\begin{tabular}{|c|c|c|c|}
\hline № & Название сборника & Годы выпуска & Кадетский корпус \\
\hline 1. & «Волец» & 1907 & Вольская военная школа \\
\hline 2. & «Донец» & с октября 1905 & Донской кадетский корпус \\
\hline 3. & «Досуг Владикавказца» & c 1910 & Владикавказский кадетский корпус \\
\hline 4. & «Кадет» & $15.10 .1906-1908$ & Сумской кадетский корпус \\
\hline 5. & «Кадет» & $1908-1916$ & 3-й Московский кадетский корпус \\
\hline 6. & $\begin{array}{l}\text { «Кадет-Михайловец» } \\
\text { «Кадет-Петровец» }\end{array}$ & $\begin{array}{l}\text { с декабря 1907; } \\
\text { 1912-1913 }\end{array}$ & 2-й кадетский корпус \\
\hline 7. & «Кадет-Михайловец» & c 1908 & $\begin{array}{l}\text { Воронежский Михайловский кадет- } \\
\text { ский корпус }\end{array}$ \\
\hline 8. & «Кадет-Сибиряк» & $1914-1915$ & $\begin{array}{l}\text { Первый Сибирский Императора Алек- } \\
\text { сандра I кадетский корпус }\end{array}$ \\
\hline 9. & «Кадетская жизнь» & $\begin{array}{c}\text { декабрь } 1906- \\
1907\end{array}$ & 2-й Московский кадетский корпус \\
\hline 10. & «Кадетская мысль» & 1907 & Нижегородский кадетский корпус \\
\hline 11. & $\begin{array}{l}\text { «Наш Листок» } \\
\text { «Кадетский досуг» }\end{array}$ & $\begin{array}{c}1903-1904 \\
25.11 .1905-1915\end{array}$ & Первый кадетский корпус \\
\hline 12. & $\begin{array}{l}\text { «Кадетский досуг» } \\
\text { «Первый труд» }\end{array}$ & $\begin{array}{l}1904-1905 \\
1906-1912 \\
\end{array}$ & Симбирский кадетский корпус \\
\hline 13. & «Кадетский сборник» & $\begin{array}{c}\text { декабрь } 1906- \\
1910\end{array}$ & $\begin{array}{l}\text { Императора Александра II кадетский } \\
\text { корпус }\end{array}$ \\
\hline 14. & $\begin{array}{l}\text { «Кадетское слово» } \\
\text { «Маленький журнал» }\end{array}$ & $\begin{array}{c}1906 \\
1907-1909 \\
\end{array}$ & Николаевский кадетский корпус \\
\hline 15. & $\begin{array}{l}\text { «Литературно-научный } \\
\text { сборник» } \\
\text { «Кадетский журнал» }\end{array}$ & $\begin{array}{c}1905-1908 \\
\text { c } 1912 \\
\end{array}$ & $\begin{array}{l}\text { Владимирский Киевский кадетский } \\
\text { корпус }\end{array}$ \\
\hline 16. & «Пажеский сборник» & c 1905 & $\begin{array}{l}\text { Пажеский Его Императорского Вели- } \\
\text { чества корпус }\end{array}$ \\
\hline 17. & «Полочанин» & $15.11 .1906-1907$ & 1-я рота Полоцкого кадетского корпуса \\
\hline
\end{tabular}

${ }^{21}$ См.: T-ов A. Кадетские журналы и сборники // Военная быль. 1964. № 66. С. 33-34; Савченко А. Кадетские журналы // Военная быль. 1960. № 40. С. 19-20. 
А. В. Агеева. Организация досуга детей и подростков в кадетских корпусах Российской империи...

Можно отметить отсутствие разнообразия в названиях, их традиционность. О содержании А. Т-ов отзывается следующим образом: «По содержанию своему журналы почти однотипны: передовые статьи, рассказы, повести, стихи, воспоминания, критика, публицистика, статьи о разных событиях в корпусе, библиография, спорт, задачи, смесь. Затрагивались любопытные темы: о внеклассном чтении, о товариществе, необходимости военного самообразования, о воинской дисциплине и т. д. Статей о русской литературе почти нет (исключение составляет “Литературно-научный сборник”...) В журналах “Пажеский сборник”, “Кадетский сборник” и “Досуг Владикавказца” принимал участие и педагогический персонал. Статьи последних носили научный характер» ${ }^{22}$.

Отметим, что популярность сборников в кадетской среде позволила возродить традицию их издания в эмиграции. Например, замечательный журнал «Кадетская перекличка», обязанный своим появлением в 1971 г. стараниям «старых кадет», издавался до 2009 г.

Говоря о кадетских сборниках, нельзя умолчать о таком замечательном примере кадетского фольклора, как «Звериада». «Звериада» представляла собой собрание шуточных стихов, песен и заметок, посвященных учебному процессу. Е. Балабин дает ей более точную характеристику: «пасквиль на преподавателей» ${ }^{23}$. Она бережно хранилась кадетами, ежегодно пополнялась и тщательно скрывалась от начальства. О существовании собственной «Звериады» упоминают кадеты Владикавказского, Донского, Орловского Бахтина и Первого кадетского корпусов.

\section{Литературно-музыкальные вечера и корпусные праздники}

О литературно-музыкальных вечерах в Первом кадетском корпусе, посвященных различным памятным датам учебного заведения, упоминает А. Н. Антонов. Среди постановок и номеров, подготовленных кадетами в разные годы, он особенно отмечает инсценировки од (кадеты, одетые в военную форму разных лет, читали специально написанные для этого дня стихотворения («оды») перед меняющимися портретами императоров и императриц соответствующей эпохи), а также инсценировку исторического урока танцев младших кадет (дети были одеты в кадетскую форму времен Екатерины Великой $)^{24}$. Эти же моменты подробнее описывает А. В. Борщов: «На сцене появился наш учитель танцев Сергей Иванович Лукьянов... в костюме XVIII в., в парике, и с ним скрипач и десяток кадет младших классов, в костюмах эпохи. Им давался урок не то гавота, не то менуэта, под звуки скрипки. Вслед за этим на эстраду выходили кадеты в исторических формах восьми царствований и прославляли достижения корпуса в ту или иную эпоху» ${ }^{25}$.

${ }^{22}$ T-ов A. Кадетские журналы и сборники // Военная быль. 1964. № 66. С. 34. C. 4 .

${ }^{23}$ Балабин Е. Донской кадетский корпус в Новочеркасске // Военная быль. 1973. № 122.

${ }^{24}$ Антонов А. Н. Первый кадетский корпус. К 235-й годовщине основания // Военная быль. 1967. № 84. С. 1-6.

${ }^{25}$ Борщов. Юбилейный бал (Из воспоминаний знаменщика 1907 года) // Военная быль. 1958. № 29. C. 26. 
Тот же А. В. Борщов упоминает о спектакле, поставленном в стенах корпуса зимой 1906 г.: «В корпусе был кадетский спектакль, поставленный на широкую ногу. Кадеты 1-й роты играли известную пьесу Бухарина “Измаил". Режиссировал артист Александровского театра Юрьев, женские роли исполняли ученицы Императорского Театрального училища ${ }^{26}$. Все декорации и костюмы были даны из складов Императорских театров... Сцена была устроена в нашем большом Сборном зале» ${ }^{27}$. Г. Месняев, закончивший Орловский корпус Бахтина, пишет о постановке пьесы «На маневрах», представлявшей собой зарисовки из армейской жизни. В Киевском кадетском корпусе ставились пьесы «Царь Эдип», «Макбет», сцены из оперы «Жизнь за царя». В Сумском кадетском корпусе ставили «Аскольдову могилу», «Недоросль», «Ревизора» и другие пьесы. Любовь сумских кадет к своему театру была так велика, что сцена для домашних спектаклей в корпусе была постоянной, то есть не разбиралась после спектаклей.

Литературно-музыкальные вечера не всегда носили официальный характер. Так, Н. Н. Доннер вспоминает о празднике-экспромте, подготовленном кадетами Первого кадетского корпуса: «Однажды, уже в пятом классе, кадеты моего отделения просили разрешения, по случаю Масленной недели, устроить после обеда маскарад. Они натащили в класс костюмы и маски, раздобыли несколько балалаек и целый вечер развлекали всю роту представлением. Было, конечно, шумно, но весело. Сам директор, обходивший в эти часы ротные помешения, от души смеялся проказам доморощенных артистов» 28 .

Участие в корпусных праздниках надолго оставляло яркий след в памяти воспитанников. Как правило, праздник состоял из нескольких частей, в числе которых обязательно присутствовали концерт и бал. Много внимания уделялось оформлению аудиторий. Выпускник Первого кадетского корпуса А. В. Борщов вспоминает: «Зал 4-й роты... превращался в подобие древне-московского терема. Картонные щиты, расписанные соответствующими узорами, закрывали упоры в стены, а своды потолка покрывались такими же расписанными узорами холстами. Получилось очень красиво и удачно. Кадеты работали под руководством опытных декораторов. Зал 3-й роты обращался в еловый лес, зимний сад с искусственным снегом на полу и на ветвях деревьев. В глубине леса были поставлены чучела волков и медведей, там же была картонная “избушка на курьих ножках”. В зале 2-й роты была отделена часть против первых дверей, убранная в виде египетской внутренности пирамиды. Стены были расписаны иероглифами, убранство - восточное, с коврами, диванами, курильницами на треножниках и т. п. Зал... 1-й роты... оставался в обычном виде, с гостиной в углу и зеленым попугаем» ${ }^{29}$. Об этих праздничных декорациях упоминает в своих мемуарах и

${ }^{26}$ Женские роли в «домашних» постановках кадет играли либо приглашенные ученицы театральных училищ, как в данном случае, либо дочери педагогов и сотрудников корпуса, либо кадеты младших курсов, одетые в женские платья.

${ }^{27}$ Борщов. Воспоминания о Первом кадетском корпусе // Военная быль. 1969. № 97. C. 17

${ }^{28}$ Доннер Н. Н. Воспоминания воспитателя о Первом кадетском корпусе // Военная быль. 1952. № 1. С. 14.

${ }^{29}$ Борщов. Юбилейный бал (Из воспоминаний знаменщика 1907 года) // Военная быль. 1958. № 29. C. 26. 
А. В. Агеева. Организация досуга детей и подростков в кадетских корпусах Российской империи...

А. Н. Антонов ${ }^{30}$. Е. Яконовский пишет о том, что подобная традиция украшения комнат к празднику была и в Оренбургском Неплюевском кадетском корпусе.

\section{Гимнастические смотры и спортивные праздники}

Гимнастические смотры относились к одному из любимых видов кадетского досуга. Проводились смотры, как правило, летом, в Петергофе, где традиционно помещался кадетский лагерь столичных корпусов. Часто на гимнастических смотрах присутствовал Государь Император и члены Императорской фамилии.

На этапе подготовки к спортивному празднику отбирались самые ловкие и выносливые мальчики и юноши из разных кадетских корпусов. Так, А. Занфиров отмечает, что в 1911 г. в состязаниях участвовали кадеты из 11 кадетских корпусов, а в 1912 - из 24. О программе выступлений он вспоминает следующее: «Программа смотра разделялась на три части: вольные движения (с палками, групповые - по три человека и так называемые сокольские фразы). Вторым номером следовала работа на снарядах и третьим - виньетка, изображавшая вензель Императора» ${ }^{31}$. Работа на снарядах включала как привычные для нас выступления - на турнике и брусьях, так и упражнения, характерные только для военно-учебных заведений. Например, прыжки через модель лошади «ласточкой», сальто-мортале и другими способами. Н. А. Косяков, также присутствовавший на этом празднике, отмечает, что на него произвели большое впечатление эти прыжки, а также сама лошадь, через которую прыгали кадеты. Она была выполнена из дерева в натуральную величину и даже поседлана ${ }^{32}$.

В кадетских корпусах, находившихся на большом расстоянии от столицы, проводились свои спортивные праздники. Например, во Владимирском Киевском кадетском корпусе такой праздник традиционно устраивался 9 мая. В программу праздника входили показательные выступления кадет в различных видах спорта, а также соревнования по стрельбе, фехтованию и гимнастике ${ }^{33}$. Гимнастический праздник с похожей программой был и в Ташкентском корпусе ${ }^{34}$. Учившийся в Донском кадетском корпусе Е. Балабин упоминает проводившиеся там «Олимпийские игры».

\section{Кадетский лагерь}

Кадетские корпуса Санкт-Петербурга в летний период вставали лагерем в Петергофе. На все лето в лагере оставались кадеты, которые по разным причинам не могли уехать в отпуск домой. Быт кадетского лагеря устраивался таким образом, чтобы максимально способствовать здоровому отдыху и развитию детей.

\footnotetext{
${ }^{30}$ Антонов. Первый кадетский корпус. К 235-й годовщине основания // Военная быль. 1967. № 84. C. 1-6.

31 Занфиров А. Смотр гимнастики в Петергофе // Военная быль. 1953. № 5. С. 17.

${ }^{32}$ Косяков Н. А. Кадетский лагерь // Военная быль. 1972. № 115. С. 6-7.

${ }^{33}$ Дубинский, Аустрин. Владимирский Киевский кадетский корпус // Военная быль. 1967. № 83. С. 1-14.

${ }^{34}$ Крылов П. И. Ташкентский наследника цесаревича Алексея Николаевича кадетский корпус (Краткая историческая справка) // Военная быль. 1971. № 110. С. 30-33.
} 
Н. А. Косяков, несколько раз остававшийся в Петергофе на все лето, А. Н. Антонов и Н. Н. Доннер, бывший воспитателем корпуса, упоминают следующие формы организации в этом лагере кадетского досуга ${ }^{35}$ :

- шахматные турниры,

• игры на воздухе (теннис, крокет и др.),

- купание,

• футбольные матчи (устраивались между местной кадетской сборной и другими командами на специально подготовленном футбольном поле),

- ярмарка (устраивалась традиционно на праздник Петра и Павла, сопровождалась катанием на качелях, играми, лотереей, балаганными выступлениями и т. д.),

- экскурсии по Петергофу,

- катания на пароходе,

- концерты в нижнем парке (во время концерта кадеты получали полную свободу: они могли слушать музыку, общаться со знакомыми барышнями, гулять, заниматься своими делами. После окончания концерта все были обязаны собраться в заранее определенном месте и вернуться в лагерь строем);

- штурм Петергофских фонтанов (кадетам отдавался приказ взять приступом фонтан. Атака проходила по шахматному каскаду, начиная от фонтана с Самсоном).

Лагерь Донского кадетского корпуса находился на хуторе Персиановка, недалеко от Новочеркасска. Е. Балабин упоминает следующие виды досуга в лагере:

- купание и катание на лодке,

- рыбалка,

• в качестве детской шалости - набеги на чужие огороды ${ }^{36}$.

\section{Посещение музеев, походы и юбилейные экскурсии по России}

По воскресеньям и праздникам кадет водили в музеи, театры и на экскурсии. Это являлось общей практикой. Все кадетские корпуса таким образом старались обеспечить культурное развитие воспитанников. Экскурсии могли носить познавательный характер. Иногда они организовывались в рамках изучаемых предметов, как общеобразовательных, так и специальных. Например, кадет Владимирского Киевского корпуса водили на чугунно-литейный завод, табачную фабрику, на выставку охотничьих собак, выставку летательных аппаратов и даже в анатомический театр ${ }^{37}$. В другом кадетском корпусе была организована экскурсия в солдатскую тюрьму.

${ }^{35}$ Косяков. Кадетский лагерь // Военная быль. 1972. № 115. С. 6-7; Антонов. Первый кадетский корпус. К 235-й годовщине основания // Военная быль. 1967. № 84. С. 1-6; Доннер. Воспоминания воспитателя о Первом кадетском корпусе // Военная быль. 1952. № 1. С. 12-14.

${ }^{36}$ Балабин. Донской кадетский корпус в Новочеркасске // Военная быль. 1973. № 122. C. $1-6$.

${ }^{37}$ Дубинский, Аустрин. Владимирский Киевский кадетский корпус // Военная быль. 1967. № 83. C. $1-14$. 
А. В. Агеева. Организация досуга детей и подростков в кадетских корпусах Российской империи...

Устраивались в кадетских корпусах и прогулки-походы. Кадет Псковского корпуса М. Зайцев отзывается о таких прогулках с большой теплотой: «Так называемые “дальние” воскресные прогулки знакомили нас с сельским хозяйством и жизнью крестьян. Знакомили с прекрасным зодчеством Русских православных церквей Псковско-Новгородского и более северных стилей, а также с иконописью. Они вызывали много хороших чувств, связанных с прочитанными книгами исторического характера. Каждая прогулка сопровождалась иллюстрацией быта Русской старины...» ${ }^{38}$. В Ташкентском наследника цесаревича кадетском корпусе устраивались выходы в степь с ночевками, обязательным знакомством с местным населением и его традициями; во 2-м Оренбургском кадетском корпусе зимой были популярны лыжные прогулки по льду замерзшего Урала ${ }^{39}$.

В годы, на которые попадали какие-либо исторические юбилеи (например, в 1912 г. - столетие Отечественной войны 1812 г. или в 1913 - трехсотлетие Дома Романовых), после летних экзаменов для кадет старших классов устраивались экскурсии по памятным местам, связанным с этими событиями. Экскурсии проводились «в счет каникул» и тем самым сокращали летний отдых кадета на одну-две недели. Но, не взирая на это, желающих поехать было много. Кадет Александровец Ф. Кочетов делится деталями организации такой экскурсии: «По количеству записавшихся, Министерство путей сообщения предоставляло в распоряжение корпуса один или два пульмановских вагона 3-го класса, с таким расчетом, что на каждого участника экскурсии приходилось одно спальное место и купе для сопровождающих воспитателей и преподавателей... Вагон наш будет прицепляться к разным поездам и... следовать заранее выработанному маршруту... Экскурсией руководят воспитатели и кто-нибудь из преподавателей, от которых получаем ко всему виденному интереснейшие объяснения» ${ }^{40}$. Известны также и маршруты экскурсий:

- 1912 г.: С.-Петербург - Витебск - Смоленск (с посещением смоленского Кремля) - Бородино (с посещением музея, Бородинского поля, Шевардинского редута и Спасо-Бородинского монастыря) - Москва (с посещением Поклонной горы, Дорогомиловской заставы, деревни Фили) - С.-Петербург.

- 1913 г.: С.-Петербург - Рыбинск - Ярославль - Ростов - озеро Неро Кострома (с посещением Ипатьевского монастыря) - Москва (с посещением Троице-Сергиевой Лавры) - С.-Петербург.

Итак, рассмотрев формы организации досуга в кадетских корпусах Российской империи в рамках выбранного источника, мы можем свидетельствовать об их разнообразии и насыщенности. Подробные воспоминания о праздниках, концертах, балах, спектаклях и литературно-музыкальных вечерах, походах и экскурсиях встречаются чаще, чем свидетельства о других видах досуга. Кроме того, эти воспоминания характеризуются точной детализацией происходящего и особенной эмоциональной окраской. Гимнастическим смотрам, кадетскому

38 Зайцев М. А. Походы и экскурсии в корпусе // Военная быль. 1954. № 10. С. 7.

${ }^{39}$ Крылов. Ташкентский наследника цесаревича Алексея Николаевича кадетский корпус (Краткая историческая справка) // Военная быль. 1971. № 110. С. 30-33; А.П. Картинки из жизни 2-го Оренбургского кадетского корпуса // 1965. № 74. С. 19-20.

${ }^{40}$ Кочетов Ф. Юбилейные экскурсии по России // Военная быль. 1959. № 38. С. 19. 
лагерю и некоторым видам самоорганизации кадетского досуга посвящены отдельные статьи. Остальные формы досуга упоминаются авторами вскользь, но при этом встречаются в большинстве статей.

Ключевые слова: история педагогики, военная педагогика, военно-учебные заведения Российской империи, кадетские корпуса, гендерное воспитание, внеклассная работа с подростками, формы организации детского досуга.

\title{
ORGANIZATION OF LEISURE OF CHILDREN AND ADOLESCENTS IN THE CADET CORPS OF THE RUSSIAN EMPIRE IN THE LATE XIX — EARLY XX CENTURY (ACCORDING TO THE MAGAZINE «MILITARY REALITY»)
}

\begin{abstract}
A. Ageeva
The article considers the forms of organization of leisure of children and adolescents practiced in the cadet corps of the Russian Empire in the late XIX - early XX century. The main source of research was the memories of former students of military schools, published in the journal «Military reality» in the period from 1952 to 1974. Along with the traditional activities, such as sports, excursions and tours, sources describe more complex forms of organization - corps museums, handwritten cadet magazines, organization of the cadet summer camp in Peterhof, a literary-musical soirees and performances. In general, the analysis of the sources allows us to conclude about the diversity of activities cadet, to identify common forms of leisure that are common to all educational institutions of this kind and unique, occurring in a single cadet corps, as well as to clarify some methodological features of their organization.
\end{abstract}

Keywords: history of pedagogy, military pedagogy, military-educational institutions of the Russian Empire, the cadet corps, gender education, extracurricular youth work, forms of organization of children's leisure.

\section{Список литературы}

1. А.П. Картинки из жизни 2-го Оренбургского кадетского корпуса // Военная быль. 1965. № 74. С. 19-20.

2. Антонов А. Музей Первого кадетского корпуса // Военная быль. 1965. № 77. С. 38-41.

3. Антонов A. H. Первый кадетский корпус. К 235-й годовщине основания // Военная быль. 1967. № 84. С. 1-6.

4. Балабин Е. Донской кадетский корпус в Новочеркасске // Военная быль. 1973. № 122. C. $1-6$.

5. Белевский. Суббота во Владикавказском кадетском корпусе // Военная быль. 1960. № 42. C. $20-22$. 
А. В. Агеева. Организация досуга детей и подростков в кадетских корпусах Российской империи...

6. Борщов А. В. Воспоминания о Первом кадетском корпусе // Военная быль. 1969. № 96. C. $10-16$.

7. Борщов А. В. Воспоминания о Первом кадетском корпусе // Военная быль. 1969. № 97. C. $13-20$.

8. Борщов А. В. Юбилейный бал (Из воспоминаний знаменщика 1907 года) // Военная быль. 1958. № 29. С. 26-27.

9. Брофельд А. Кадетские корпуса Российской Империи // Военная быль. 1964. № 67. C. $13-18$

10. Ветлии А. Первый кадетский корпус // Военная быль. 1962. № 54. С. 29-32.

11. Витm Д. Л., де. Из далекого прошлого // Военная быль. 1955. № 12. С. 11-13.

12. Гершельман А. С. Один из сорока трех (отрывок) // Военная быль. 1972. № 114. С. 3738.

13. Данилевич М. Оренбургский Неплюевский кадетский корпус (1825-1960) // Военная быль. 1960. № 45. С. 10-11; 1961. № 46. С. 12-13.

14. Двигубский С. Кадетские корпуса // Военная быль. 1952. № 1. С. 5-6.

15. Доннер Н. Н. Воспоминания воспитателя о Первом кадетском корпусе // Военная быль. 1952. № 1. С. 12-14.

16. Дубинский В., Аустрин Г. Владимирский Киевский кадетский корпус // Военная быль. 1967. № 83. С. 1-14.

17. Зайцев М. А. Из воспоминаний о Пскове // Военная быль. 1953. № 6. С. 13-16.

18. Зайцев М. А. Походы и экскурсии в корпусе // Военная быль. 1954. № 10. С. 6-7.

19. Занфиров А. Смотр гимнастики в Петергофе // Военная быль. 1953. № 5. С. 17-18.

20. Каменский B. Воспоминания об Александровском кадетском корпусе // Военная быль. 1973. № 124. С. 22-26.

21. Каменский В. Корпусный лазарет: из цикла «Корпус императора Александра II» // Военная быль. 1960. № 41. С. 20-22.

22. Каратеев М. Лазаретные воспоминания // Военная быль. 1961. № 46. С. 17-19.

23. Косяков Н. А. Кадетский лагерь // Военная быль. 1972. № 115. С. 6-7.

24. Косяков Н. А. Нечто о «Звериаде» // Военная быль. № 109. С 33-34.

25. Кочетов Ф. Манежная езда и конный праздник // Военная быль. 1960. № 40. С. $20-21$.

26. Кочетов Ф. Юбилейные экскурсии по России // Военная быль. 1959. № 38. С. 19-21.

27. Крылов П. И. Ташкентский наследника цесаревича Алексея Николаевича кадетский корпус (Краткая историческая справка) // Военная быль. 1971. № 110. С. 30-33.

28. Месняев Г. Кадетские годы (1902-1909) // Военная быль. 1954. № 11. С. 2-6; 1955. № 12. С. 4-9; № 13. С. 6-10; № 14. С. 9-13; № 15. С. 4-7; 1956. № 16. С. 7-12.

29. Новиков В. Корпусной праздник // Военная быль. 1961. № 50. С. 11-14.

30. Ряснянский Б. Сумский кадетский корпус: Воспоминания // Военная быль. 1971. № 112. С. 6-12.

31. Савченко А. Кадетские журналы // Военная быль. 1960. № 40. С. 19-20.

32. Т-ов А. Кадетские журналы и сборники // Военная быль. 1964. № 66. С. 33-34.

33. Ф. K. Кадетская охота (Из цикла «Корпус императора Александра II») // Военная быль. 1959. № 36. С. 18-19.

34. Цимбалюк В. Авиаторы // Военная быль. 1959. № 36. С. 16-17.

35. Цимбалюк В. Пиротехники // Военная быль. 1961. № 49. С. 43-45.

36. Яконовский Е. Каргалла // Военная быль. 1952. № 2. С. 18-24. 